\title{
$\beta$-Lactamase inhibition profile of new amidine-substituted diazabicyclooctanes
}

\author{
Zafar lqbal ${ }^{\ddagger 1}$, Lijuan Zhai ${ }^{\ddagger 1}$, Yuanyu Gao ${ }^{1}$, Dong Tang ${ }^{1}$, Xueqin $\mathrm{Ma}^{2}$, Jinbo $\mathrm{Ji}^{1}$, \\ Jian Sun ${ }^{1}$, Jingwen $\mathrm{Ji}^{1}$, Yuanbai Liu ${ }^{1}$, Rui Jiang ${ }^{1}$, Yangxiu Mu ${ }^{1}$, Lili He ${ }^{1}$, Haikang Yang ${ }^{* 1}$ \\ and Zhixiang Yang ${ }^{* 1}$
}

\section{Full Research Paper}

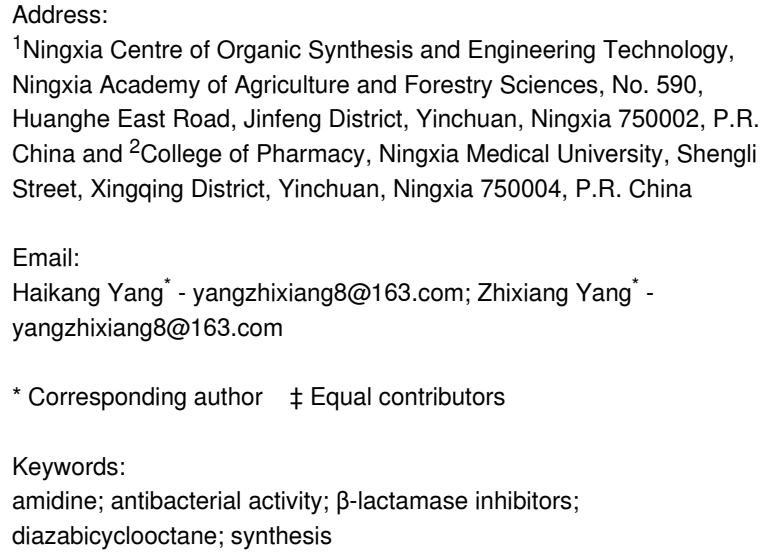

\author{
Beilstein J. Org. Chem. 2021, 17, 711-718. \\ https://doi.org/10.3762/bjoc. 17.60 \\ Received: 19 December 2020 \\ Accepted: 26 February 2021 \\ Published: 12 March 2021 \\ Associate Editor: J. S. Dickschat \\ (C) 2021 lqbal et al.; licensee Beilstein-Institut. \\ License and terms: see end of document.
}

\begin{abstract}
The diazabicyclooctane (DBO) scaffold is the backbone of non- $\beta$-lactam-based second generation $\beta$-lactamase inhibitors. As part of our efforts, we have synthesized a series of DBO derivatives A1-23 containing amidine substituents at the C2 position of the bicyclic ring. These compounds, alone and in combination with meropenem, were tested against ten bacterial strains for their antibacterial activity in vitro. All compounds did not show antibacterial activity when tested alone (MIC >64 mg/L), however, they exhibited a moderate inhibition activity in the presence of meropenem by lowering its MIC values. The compound A12 proved most potent among the other counterparts against all bacterial species with MIC from $<0.125 \mathrm{mg} / \mathrm{L}$ to $2 \mathrm{mg} / \mathrm{L}$, and is comparable to avibactam against both $E$. coli strains with a MIC value of $<0.125 \mathrm{mg} / \mathrm{L}$.
\end{abstract}

\section{Introduction}

Survival stress posed by antimicrobial agents triggers multiple mechanisms [1] in microorganisms ultimately leading to the initiation of antibiotic resistance and survival of the microorganisms [2]. In case of Gram-negative pathogenic bacteria, production of $\beta$-lactamases [3] is the main arsenal of these microorgan- isms against antibiotics. The number of $\beta$-lactamases is increasing day by day thereby indicating the strength of these pathogens in compromising the efficacy of new antibiotics after a certain period of time. Recently, the WHO warned about the seriousness of carbapenemase-resistant Gram-negative bacteria 
as a global threat and urged for the development of new remedies [4].

$\beta$-Lactams (BL) have served as the first line antibiotics since the introduction of penicillin. However, due to existence and continuous increase in $\beta$-lactamases [5], multidrug therapy is becoming the new modality of bacterial treatment against multiple-drug resistant (MDR) bacteria. Multidrug therapy employs the combination of an existing antibiotic with a $\beta$-lactamase inhibitor (BLI). A few of BLI/BL combinations have been approved [6] so far for clinical applications by different countries, clavulanic acid/amoxicillin (augmentin) [7-9] being the first one, while others are in clinical trials [6]. Although augmentin [10] was successfully applied to treat the infections caused by bacterial strains producing Ambler class A and extended spectrum $\beta$-lactamases (ESBLs) [11], the emergence of new and mutant class A $\beta$-lactamases compromised its effectiveness overtime [10,12]. Subsequently, sulbactam and tazobactam [13] evolved as the BLIs of class A, B and few of class D $\beta$-lactamases [14]. These inhibitors were advantageous to clavulanic acid due to their lack of chromosomal induction of AmpC but found susceptible to a few of class A enzymes such as TEM type [10] and CTX-M (ESBL), identified in Escherichia coli clinical isolates [14,15].

The diazabicyclooctane (DBO) [16] ring suggested as an alternative to the $\beta$-lactam ring [17] by the Hoechst researchers [16] could not prove its antibacterial strength in early experiments rather it showed $\beta$-lactamase inhibition activity. This discovery led the researchers to develop second generation $\beta$-lactamase inhibitors, finally succeeded with the approval of avibactam and relebactam as non- $\beta$-lactam-based BLIs. Avibactam proved potent as inhibitor of Klebsiella pneumoniae carbapenemases (KPCs), AmpCs and some of class D $\beta$-lactamases [18] is now in clinical practice in combination with ceftazidime [6]. Followed by avibactam, a relebactam/imipenem/cilastatin [6] combination has been approved by the FDA for the treatment of clinical indications against carbapenemases, ESBLs, and MDR Enterobacteriaceae as well as Pseudomonas aeruginosa [19$21]$. Of note, these combinations are not effective against class B metallo-lactamases and most of class D (OXA) $\beta$-lactamases. Therefore, several other DBO-based BLIs [17], such as durlobactam, nacubactam [22], zidebactam, ETX0282, ARX1796 (a prodrug of avibactam) [23], and WCK 4234 [18,24] are passing through phase I and phase III clinical trials $[6,25]$ in combination with different types of $\beta$-lactams.

These multidrug combinations have shown promise for future antibiotic regime and drug development based on non- $\beta$-lactam inhibitors. Nonetheless, a partial loss of activity has been reported in case of the ceftazidime/avibactam combination due to overproduction of AmpC cephalosporinases [26]. In another report it has been concluded that ESBLs of the GES, PER and BEL types in E. coli and $P$. aeruginosa conferred resistance against sulbactam and avibactam combinations [27]. Therefore, it is utmost necessary to continue the struggle with exploring new inhibitors capable of improved resistance and activity against all classes of $\beta$-lactamases. Based on our ongoing efforts towards the synthesis of new DBO-based BLIs, we have synthesized a number of amidine-conjugated derivatives of avibactam. Herein, we report the synthesis, and antibacterial as well as inhibitory activities of these compounds, alone and in combination with meropenem (MER), in comparison to avibactam alone and its combination with MER, an existing antibiotic in clinics.

\section{Results and Discussion Synthesis of intermediates 1-5}

The preparation of intermediate $\mathbf{1}$ is the key step for the synthesis of the final compounds (Scheme 1). Compound 1 was synthesized by dehydration of amide [28] 6 which is commercially available. Dehydration was achieved by reacting 6 with trifluoroacetic anhydride in $\mathrm{CH}_{2} \mathrm{Cl}_{2}$ at room temperature (rt) and is described elsewhere [18]. Conversion of the cyano compound $\mathbf{7}$ into the corresponding amidine compound $\mathbf{1}$, the key intermediate, proved cumbersome. Several experiments and reagents [29] were tried before finding trimethylaluminum $\left(\mathrm{Al}(\mathrm{Me})_{3}\right)$ and $\mathrm{NH}_{4} \mathrm{Cl}[30]$ as the reagents of choice for this conversion. As a result, compound 7 was reacted with $\mathrm{Al}(\mathrm{Me})_{3}$ and $\mathrm{NH}_{4} \mathrm{Cl}$ to furnish amidine $\mathbf{1}$ in $\mathrm{CH}_{2} \mathrm{Cl}_{2}$ starting the reaction at low temperature followed by increasing the temperature to ambient temperature for $16 \mathrm{~h}$. Amidine 1 was obtained in $44 \%$ yield after purification by column chromatography using $\mathrm{MeOH}$ and $\mathrm{CH}_{2} \mathrm{Cl}_{2}$. The low yield of this reaction was due to the formation of two isomeric products as revealed by TLC and subsequent analysis by analytical LC-MS. The NMR spectra of both isomers, after chromatographic separation, showed different chemical shifts for the protons at C2 position of the DBO ring, indicating a racemization during the reaction process. The less polar isomer with $R$-configuration [31,32] at $\mathrm{C} 2$ showed a complete loss of $\beta$-lactamase inhibition activity as compared to the more polar isomer. Therefore, the less polar isomer was

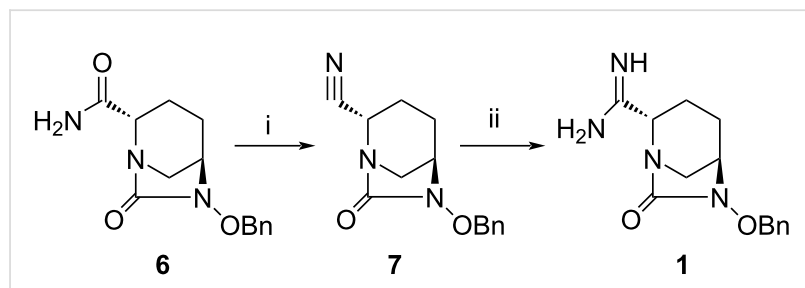

Scheme 1: Synthesis of intermediate 1. Reagents and conditions: (i) trifluoroacetic anhydride, $\mathrm{CH}_{2} \mathrm{Cl}_{2}, 0-35{ }^{\circ} \mathrm{C}, 3 \mathrm{~h}, 64 \%$; (ii) $\mathrm{Al}(\mathrm{Me})_{3}$, $\mathrm{NH}_{4} \mathrm{Cl}, \mathrm{CH}_{2} \mathrm{Cl}_{2}, 0^{\circ}-\mathrm{rt}, 16 \mathrm{~h}, 44 \%$. 
discarded while saving the more polar $S$-isomer, (relative ratio of $S: R$ isomers $=6: 1)$.

The synthesis of intermediate $\mathbf{2}$ started from the hydrogenation of 7 by following a previously described method using $N, N$ dimethylformamide (DMF) $/ \mathrm{CH}_{2} \mathrm{Cl}_{2}$ [23] as solvent led to a low yield in our hands. Therefore, we planned to switch the solvent from DMF to EtOAc whereupon the yield improved, however, still an amino derivative as side product was observed. The addition of $\mathrm{CH}_{2} \mathrm{Cl}_{2}$ with ethyl acetate proved helpful in increasing the yield and the NMR of the crude product $\mathbf{8}$ was acceptable to use it for further reaction without purification. The hydroxy group in $\mathbf{8}$ was then protected by TBS (tert-butyldimethylsilane) using tert-butyldimethylsilyl chloride (9, TBSCl) and imidazole in $\mathrm{CH}_{2} \mathrm{Cl}_{2}$. The thus obtained derivative 10 was then subjected to an amidination by $\mathrm{Al}(\mathrm{Me})_{3}$ and $\mathrm{NH}_{4} \mathrm{Cl}$ to afford amidine $\mathbf{2}$ (Scheme 2).

Compounds 3 and $\mathbf{4}$ were prepared from commercially available compounds $\mathbf{1 1}$ and 12, respectively, in two steps. In the first step, the ester derivatives were $\mathrm{N}$-acylated by acetic anhydride in $\mathrm{CH}_{2} \mathrm{Cl}_{2}$ followed by hydrolysis using aqueous $\mathrm{NaOH}$ in THF to afford the required intermediates $\mathbf{3}$ and $\mathbf{4}$ in overall good yields. Compound $\mathbf{5}$ was obtained by direct acylation of the commercially available acid $\mathbf{1 3}$ using acetic anhydride and a stoichiometric amount of water at room temeprature (Scheme 3).

\section{Synthesis of compounds A1-23}

The synthesis of compounds A1-21 starting from intermediate $\mathbf{1}$ was accomplished as depicted in Scheme 4. The coupling of the organic acids with amidine $\mathbf{1}$ to form the corresponding derivatives B1-21 was achieved by common coupling reagents such as $N, N^{\prime}$-dicyclohexylcarbodiimide (DCC) or $(O$-(7-aza$1 H$-benzotriazol-1-yl)- $N, N, N^{\prime}, N^{\prime}$-tetramethyluronium hexafluorophosphate) (HATU) [33] in DMF or $\mathrm{CH}_{2} \mathrm{Cl}_{2}$ with either $N, N$-diisopropylethylamine (DIPEA) or 4-dimethylaminopyridine (DMAP) as the base. Then, the palladium-catalyzed hydrogenation of compounds B1-21 in THF or EtOAc led to the hydroxy derivatives C1-21. It has been observed that a cata-

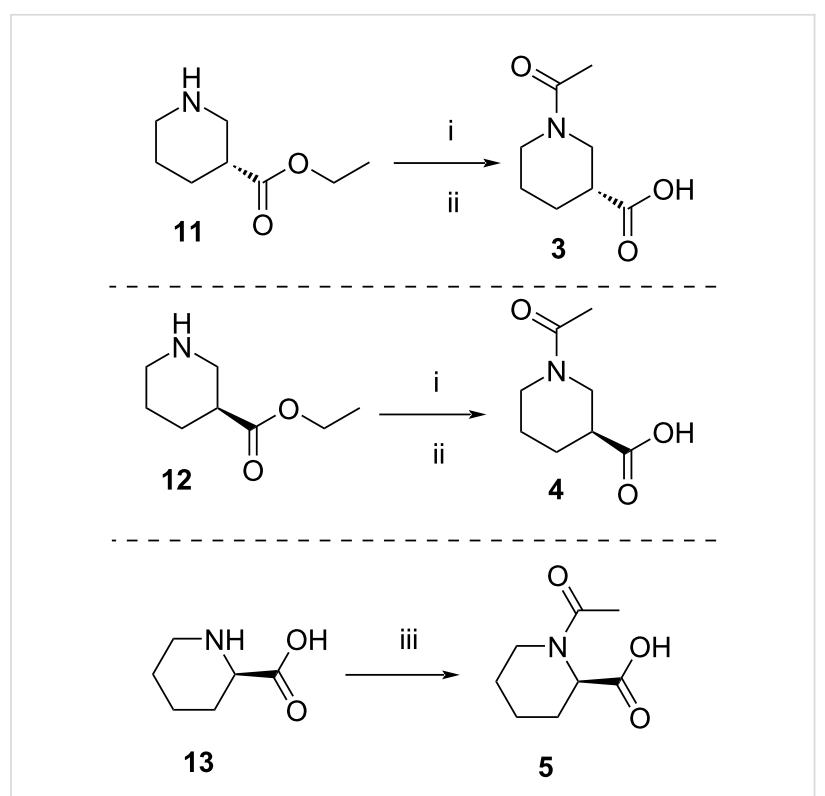

Scheme 3: Synthesis of intermediates 3-5. Reagents and conditions: (i) $(\mathrm{Ac})_{2} \mathrm{O}, \mathrm{CH}_{2} \mathrm{Cl}_{2}, \mathrm{rt}, 24 \mathrm{~h}, 95-99 \%$; (ii) aqueous $\mathrm{NaOH}, 0^{\circ} \mathrm{C}, 2 \mathrm{~h}$, 85-99\%; (iii) $(\mathrm{Ac})_{2} \mathrm{O}, \mathrm{H}_{2} \mathrm{O}$, rt, $3 \mathrm{~h}, 68 \%$.

lytic amount of triethylamine (TEA) in EtOAc enhances the rate of the hydrogenolysis of benzyl ethers. Compounds C1-21 were then reacted with $\mathrm{SO}_{3}$.pyridine to form sulfonic acid derivatives A1-21 after purification by preparative HPLC. The sodium salts of these compounds were obtained by ion exchange using a column filled with Dowex-50wx $\mathrm{Na}^{+}$resin using water as the eluent, followed by lyophilization. In case of compound A18, Boc deprotection was achieved by using trifluoroacetic acid (TFA) before the preparative HPLC.

The synthesis of compounds A22 and A23 was accomplished by an alternative route elaborated in Scheme 5. Coupling of compound $\mathbf{5}$ and intermediate $\mathbf{2}$ was achieved by using HATU and DIPEA in a $\mathrm{DMF} / \mathrm{CH}_{2} \mathrm{Cl}_{2}$ mixture to form the derivative B22 which was treated with tetrabutylammonium fluoride (TBAF) in THF to obtain the hydroxy derivative C22. Compound $\mathbf{C 2 2}$ was converted to the sodium salt of $\mathbf{A 2 2}$ by using the procedure described for derivative A1. Analogously, com-<smiles></smiles>

7

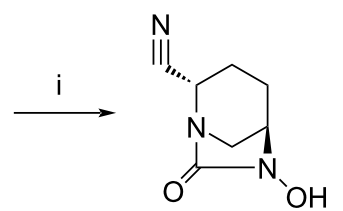

8

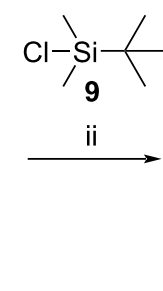<smiles>N#C[C@@H]1CCC2CC1N([OH+][Sb])C2=O</smiles>

10

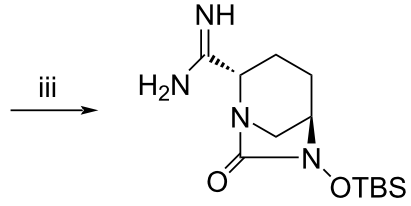

2

Scheme 2: Synthesis of intermediate 2. Reagents and conditions: (i) $\mathrm{Pd} / \mathrm{C}$ (wet), $\mathrm{EtOAc} / \mathrm{CH}_{2} \mathrm{Cl}_{2}, \mathrm{H}_{2}, 45 \mathrm{psi}$, rt, $2 \mathrm{~h}, 95 \%$; (ii) imidazole, $\mathrm{CH}_{2} \mathrm{Cl}_{2}$, rt, $16 \mathrm{~h}, 46 \%$; (iii) $\mathrm{Al}(\mathrm{Me})_{3}, \mathrm{NH}_{4} \mathrm{Cl}, \mathrm{CH}_{2} \mathrm{Cl}_{2}, 0{ }^{\circ} \mathrm{C}-\mathrm{rt}, 40 \mathrm{~h}, 23 \%$. 

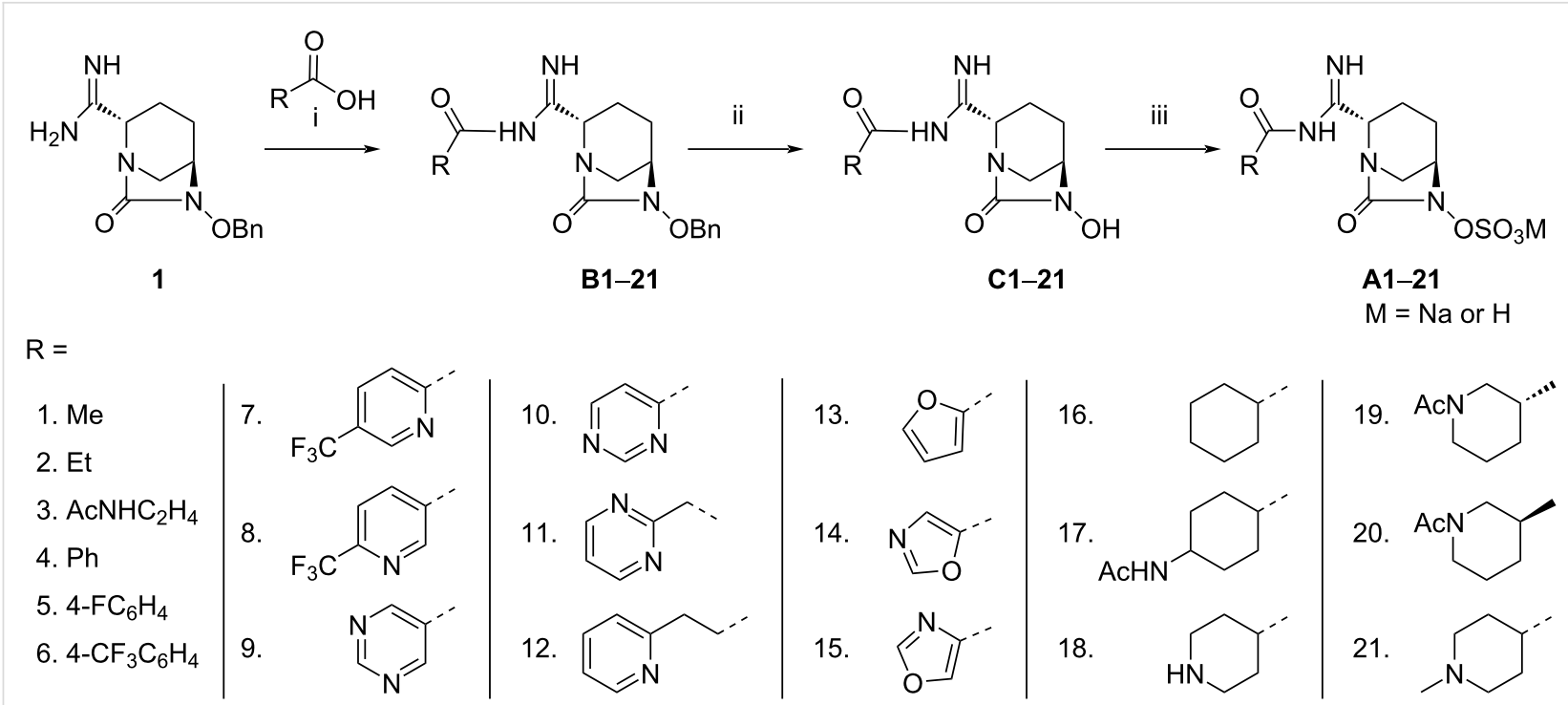

10.<smiles>Cc1ccncn1</smiles>

11.<smiles>CCc1ncccn1</smiles>

12.<smiles>CCCc1ccccn1</smiles>

13.<smiles>Cc1cocn1</smiles>

16.<smiles>CC1CCCCC1</smiles>

17.<smiles>CC1CCC(NC(C)C)CC1</smiles>

19.<smiles></smiles>

20.<smiles>CC(=O)N1CCCC(C)C1</smiles>

21.<smiles>CC1CCN(C)CC1</smiles>

Scheme 4: Synthesis of compounds A1-21. Reagents and conditions: (i) acetyl chloride, TEA, $\mathrm{CH}_{2} \mathrm{Cl}_{2}, \mathrm{rt}, 16 \mathrm{~h}, 97 \%$ (for B1), HATU, DIPEA or DCC,

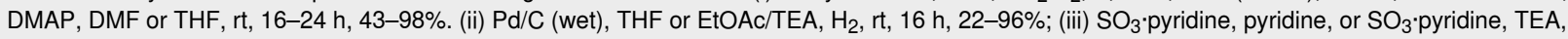
$\mathrm{THF} / \mathrm{water}, \mathrm{rt}, 16 \mathrm{~h}$, or then Dowex-50wx $\mathrm{Na}^{+}, 8-99 \%$.

pound $\mathbf{A 2 3}$ was prepared starting from 4-aminothiazole-2carboxylic acid and amidine derivative 2 (Scheme 5) according to the procedures described for $\mathbf{A 2 2}$.

\section{In vitro antibacterial efficacy}

We synthesized a series of amidine derivatives of avibactam containing a variety of substituents, forming amide linkage with $\mathrm{NH}_{2}$ of amidine of the parent intermediate $\mathbf{1}$ or $\mathbf{2}$. The different kinds of substituents $(\mathrm{R})$ introduced in the final compounds A1-23 are depicted in Table 1. In vitro antibacterial activities of compounds A1-23 were determined first without combining the compounds with an antibacterial drug and the minimum inhibitor concentration (MIC) of each compound was determined for all ten bacterial strains, i.e., E. coli clinical isolate, E. coli 8739, K. pneumoniae clinical isolate, K. pneumoniae 700603 , E. cloacae clinical isolate, E. cloacae 700323, A. baumannii clinical isolate, A. baumannii 19606, P. aeruginosa clinical isolate, and $P$. aeruginosa 9027 (Table 1). All newly synthesized compounds showed MIC values $>64 \mathrm{mg} / \mathrm{L}$ against all tested bacterial species. For comparison, the MIC values of avibactam against the bacterial strains were also determined and were found comparable to the synthesized compounds (MIC $>64 \mathrm{mg} / \mathrm{L}$ ). This indicates that both, avibactam and compounds A1-23 are not antibacterial in action when used alone. Next, we determined the antibacterial activity of meropenem (MER) alone and in combination with avibactam as well as in combina-

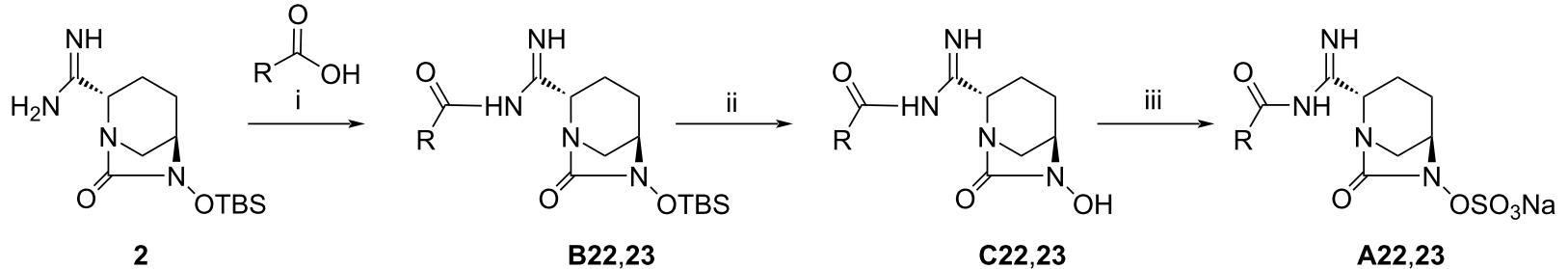<smiles>[R20]C1CCC(C)CC1N1CCCCC1</smiles>

Scheme 5: Synthesis of compounds A22 and A23. Reagents and conditions: (i) HATU, DIPEA or DCC, DMAP, DMF or THF, rt, $16 \mathrm{~h}, 62 \%$ (B22), 80\% (B23); (ii) TBAF, THF, 80\% (C22), 92\% (C23); (iii) $\mathrm{SO}_{3}$ ·pyridine, pyridine, or $\mathrm{SO}_{3} \cdot$ pyridine, TEA, THF/water, rt, $16 \mathrm{~h}$, then Dowex-50 $\mathrm{wx} \mathrm{Na}^{+}, 83 \%$ (A22), 35\% (A23). 
Table 1: In vitro antibacterial activity of avibactam and compounds A1-23 alone as well as in combination with meropenem (MER).

\begin{tabular}{|c|c|c|c|c|c|c|c|c|c|c|c|}
\hline & & E. coli ${ }^{\mathrm{a}}$ & E. colib & $K \cdot p^{c}$ & $K \cdot p^{\mathrm{d}}$ & $E . c^{\mathrm{e}}$ & $E . c^{f}$ & $A . b^{g}$ & $A \cdot b^{\mathrm{h}}$ & $P . a^{\mathrm{i}}$ & P. $a^{\mathrm{j}}$ \\
\hline & $\begin{array}{l}\text { A1-23, } \\
\text { avibactam alone }\end{array}$ & $>64$ & $>64$ & $>64$ & $>64$ & $>64$ & $>64$ & $>64$ & $>64$ & $>64$ & $>64$ \\
\hline & MER alone & 4 & 4 & 4 & 2 & 4 & 4 & 4 & 2 & 4 & 4 \\
\hline & $\begin{array}{l}\mathrm{MER}+ \\
\text { avibactam }\end{array}$ & $<0.125$ & $<0.125$ & $<0.125$ & $<0.125$ & $<0.125$ & $<0.125$ & 1 & 0.5 & 0.5 & 0.25 \\
\hline \multicolumn{12}{|l|}{ R: } \\
\hline $\mathrm{Me}$ & $\mathrm{MER}+\mathbf{A} 1$ & 0.5 & $<0.125$ & 2 & 0.5 & 2 & 1 & 2 & 0.5 & 0.5 & 1 \\
\hline Et & $\mathrm{MER}+\mathbf{A} 2$ & 0.5 & $<0.125$ & 2 & 1 & 2 & 2 & 2 & 0.5 & 0.5 & 0.5 \\
\hline $\mathrm{AcNHC}_{2} \mathrm{H}_{4}$ & $\mathrm{MER}+\mathbf{A} \mathbf{3}$ & $<0.125$ & 0.25 & 1 & 0.25 & 1 & 1 & 2 & 0.5 & 0.5 & 1 \\
\hline $\mathrm{Ph}$ & $\mathrm{MER}+\mathbf{A 4}$ & 2 & 0.25 & 1 & 0.25 & 2 & 0.25 & 2 & 0.5 & 2 & 1 \\
\hline $4-\mathrm{FC}_{6} \mathrm{H}_{4}$ & $\mathrm{MER}+\mathbf{A 5}$ & 1 & 0.25 & 2 & 0.25 & 2 & 1 & 2 & 1 & 1 & 1 \\
\hline \multirow[t]{3}{*}{$4-\mathrm{CF}_{3} \mathrm{C}_{6} \mathrm{H}_{4}$} & $\mathrm{MER}+\mathbf{A} \mathbf{6}$ & 0.5 & 0.25 & 2 & 0.5 & 2 & 2 & 2 & 0.5 & 1 & 0.5 \\
\hline & $\mathrm{MER}+\mathbf{A} \mathbf{7}$ & 1 & 0.25 & 2 & 0.5 & 2 & 1 & 2 & 0.5 & 0.5 & 1 \\
\hline & $\mathrm{MER}+\mathbf{A} \mathbf{8}$ & 0.5 & $<0.125$ & 2 & 0.5 & 2 & 2 & 2 & 0.5 & 0.5 & 1 \\
\hline & $\mathrm{MER}+\mathbf{A} \mathbf{9}$ & 0.5 & 0.5 & 2 & 1 & 2 & 2 & 2 & 1 & 1 & 2 \\
\hline & $\mathrm{MER}+\mathbf{A} 10$ & 1 & 0.5 & 2 & 0.5 & 2 & 1 & 2 & 0.5 & 0.5 & 1 \\
\hline & $\mathrm{MER}+\mathbf{A} 11$ & 0.25 & 0.25 & 0.25 & 0.25 & 0.5 & 1 & 2 & 0.5 & 0.25 & 1 \\
\hline & $\mathrm{MER}+\mathbf{A} 12$ & $<0.125$ & $<0.125$ & $<0.125$ & $<0.125$ & 0.5 & 0.5 & 2 & 1 & 0.25 & 0.5 \\
\hline & $\mathrm{MER}+\mathbf{A} 1 \mathbf{3}$ & 0.5 & $<0.125$ & 2 & 0.25 & 2 & 1 & 2 & 0.5 & 0.5 & 1 \\
\hline & MER + A14 & 0.25 & 0.25 & 0.25 & 0.25 & 2 & 0.25 & 2 & 0.5 & 0.25 & 1 \\
\hline & $\mathrm{MER}+\mathbf{A} 15$ & 0.25 & 0.25 & 0.25 & 0.25 & 2 & 1 & 2 & 1 & 0.25 & 1 \\
\hline & $\mathrm{MER}+\mathbf{A} 16$ & 1 & $<0.125$ & 2 & 0.25 & 2 & 0.5 & 2 & 0.5 & 0.5 & 0.5 \\
\hline & MER + A17 & 0.25 & 0.25 & 0.25 & 0.25 & 1 & 1 & 2 & 0.5 & 0.25 & 0.5 \\
\hline & $\mathrm{MER}+\mathbf{A} 18$ & 0.25 & 0.5 & 0.25 & 0.25 & 2 & 1 & 2 & 2 & 1 & 0.25 \\
\hline & MER + A19 & 0.25 & 0.25 & 2 & 0.25 & 1 & 0.5 & 2 & 1 & 1 & 0.5 \\
\hline
\end{tabular}


Table 1: In vitro antibacterial activity of avibactam and compounds A1-23 alone as well as in combination with meropenem (MER). (continued)

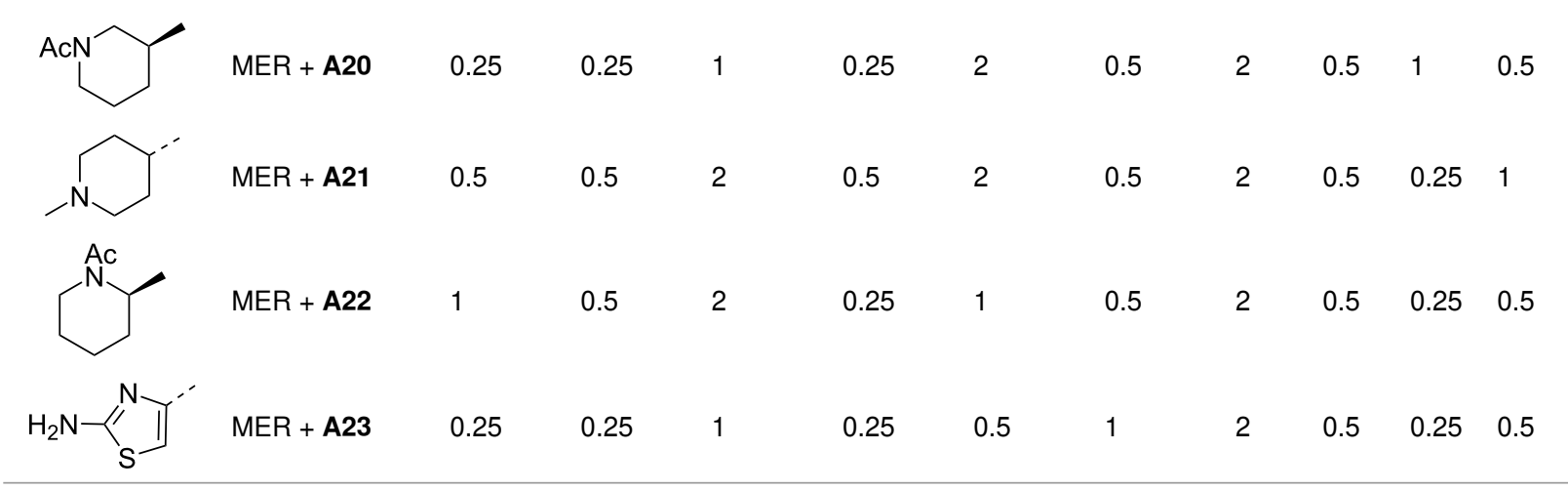

${ }^{a} E$. coli clinical isolate; ${ }^{b} E$. coli 8739; ${ }^{c} K$. pneumoniae clinical isolate; d K. pneumoniae 700603 ; e $E$. cloacae clinical isolate; ${ }^{\mathrm{t}} E$. cloacae 700323 ; ${ }^{g} A$. baumannii clinical isolate; ${ }^{\mathrm{h}} A$. baumannii 19606; i $P$. aeruginosa clinical isolate; ${ }^{\mathrm{P}} \mathrm{P}$. aeruginosa 902.

tion with the synthesized compounds A1-23. From Table 1, it can be deduced that the antibacterial activity of MER increased in the presence of avibactam $(4 \mathrm{mg} / \mathrm{L})$ in all bacterial strains under observation. The MIC values of MER without avibactam were observed to be in the range of $2 \mathrm{mg} / \mathrm{L}$ to $4 \mathrm{mg} / \mathrm{L}$, whereas after the addition of avibactam the antibacterial activity changed to $<0.125 \mathrm{mg} / \mathrm{L}-1 \mathrm{mg} / \mathrm{L}$, indicating the enzyme inhibition effect of avibactam.

In order to establish the lactamase inhibition effect of the synthesized avibactam derivatives A1-23, we determined the antibacterial activity of MER in combination with compounds A1-23 individually. The results are summarized in Table 1 as MIC values of each compound against each bactrial strain. From Table 1 it is evident that all compounds enhanced the antibacterial activity of MER (MIC $<0.125 \mathrm{mg} / \mathrm{L}$ to $2 \mathrm{mg} / \mathrm{L}$ ) as compared to meropenem alone (MIC $2 \mathrm{mg} / \mathrm{L}$ to $4 \mathrm{mg} / \mathrm{L}$ ). Compound $\mathbf{A 1 2}$ proved to be the most potent compound among the other counterparts against all bacterial species with MIC values from $<0.125 \mathrm{mg} / \mathrm{L}$ to $2 \mathrm{mg} / \mathrm{L}$, and is comparable to avibactam against both $E$. coli strains and $K$. pneumoniae strains with a MIC value of $<0.125 \mathrm{mg} / \mathrm{L}$. From the data in Table 1 it is evident that the A. baumannii clinical isolate is the most resistant strain against all newly synthesized compounds as well as against avibactam showing MIC values of $2 \mathrm{mg} / \mathrm{L}$ and $1 \mathrm{mg} / \mathrm{L}$, respectively. However, E. coli 8739 was the most susceptible strain to most of the synthesized compounds for example, A1, A2, A8, A12, A13 and A16 with a MIC value of $<0.125 \mathrm{mg} / \mathrm{L}$.

Although a comprehensive conclusion cannot be drawn about the structure-activity relationship of the compounds, a few points could be ascertained. For example, varying the substituents $(\mathrm{R})$ at the amidine attached to the $\mathrm{C} 2$ position of the DBO ring definitely tuned the antibacterial activity of the compounds
A1-23. Further, aromatic substituents proved slightly better than alkyl substituents against most of the bacterial strains, however, stereochemically isomeric substituents (e.g., in A19 and A20) did not pose a substantial effect on the activity.

\section{Conclusion}

We have successfully synthesized a series of avibactam derivatives with substituted amidines at the $\mathrm{C} 2$ position of DBO in moderate to good overall yields. In vitro antibacterial testing of the compounds was performed against ten bacterial strains containing different $\beta$-lactamase enzymes. The compounds were tested alone and in combination with the existing antibiotic, meropenem. All compounds showed no antibacterial efficacy when tested alone, however, all compounds exhibited a moderate antibacterial activity in combination with meropenem. This confers the $\beta$-lactamase inhibition activity of these compounds as illustrated by reduced MIC values of meropenem in the presence of the test compounds. Compound $\mathbf{A 1 2}$ was the most potent inhibitor in case of all bacterial strains under observation and may be a lead compound for further development.

\section{Supporting Information}

\section{Supporting Information File 1}

Detailed experimental protocols, ${ }^{1} \mathrm{H}$ NMR, LC-MS data, and copies of ${ }^{1} \mathrm{H}$ NMR spectra of the final compounds.

[https://www.beilstein-journals.org/bjoc/content/ supplementary/1860-5397-17-60-S1.pdf]

\section{Funding}

Ministry of Science and Technology, P.R. China is gratefully acknowledged for the award of foreign expert program to Dr. 
Haikang Yang and Dr. Zafar Iqbal. This work was supported by the grant from Science and Technology Department of Ningxia, P.R. China (No. 2018BCG01001).

\section{ORCID ${ }^{\circledR}$ iDs}

Zafar lqbal - https://orcid.org/0000-0003-2490-3805

\section{Preprint}

A non-peer-reviewed version of this article has been previously published as a preprint: https://doi.org/10.3762/bxiv.2020.143.v1

\section{References}

1. Wencewicz, T. A. J. Mol. Biol. 2019, 431, 3370-3399. doi:10.1016/j.jmb.2019.06.033

2. Peterson, E.; Kaur, P. Front. Microbiol. 2018, 9, 2928-2948. doi:10.3389/fmicb.2018.02928

3. Tooke, C. L.; Hinchliffe, P.; Bragginton, E. C.; Colenso, C. K.; Hirvonen, V. H. A.; Takebayashi, Y.; Spencer, J. J. Mol. Biol. 2019, 431, 3472-3500. doi:10.1016/j.jmb.2019.04.002

4. Bloom, D. E.; Cadarette, D. Front. Immunol. 2019, 10, 549-560. doi:10.3389/fimmu.2019.00549

5. Bush, K.; Bradford, P. A. Clin. Microbiol. Rev. 2020, 33, e00047-19. doi:10.1128/cmr.00047-19

6. Butler, M. S.; Paterson, D. L. J. Antibiot. 2020, 73, 329-364. doi:10.1038/s41429-020-0291-8

7. Saudagar, P. S.; Survase, S. A.; Singhal, R. S. Biotechnol. Adv. 2008, 26, 335-351. doi:10.1016/j.biotechadv.2008.03.002

8. Finlay, J.; Miller, L.; Poupard, J. A. J. Antimicrob. Chemother. 2003, 52, 18-23. doi:10.1093/jac/dkg286

9. Drug Ther. Bull. 1996, 34, 76-79. doi:10.1136/dtb.1996.341076

10. Blazquez, J.; Baquero, M. R.; Canton, R.; Alos, I.; Baquero, F. Antimicrob. Agents Chemother. 1993, 37, 2059-2063. doi:10.1128/aac.37.10.2059

11. Ghafourian, S.; Sadeghifard, N.; Soheili, S.; Sekawi, Z. Curr. Issues Mol. Biol. 2015, 17, 11-22. doi:10.21775/cimb.017.011

12. Papp-Wallace, K. M.; Bonomo, R. A. Infect. Dis. Clin. North Am. 2016, 30, 441-464. doi:10.1016/j.idc.2016.02.007

13. Shlaes, D. M. Ann. N. Y. Acad. Sci. 2013, 1277, 105-114. doi:10.1111/nyas.12010

14. Bush, K.; Bradford, P. A. Cold Spring Harbor Perspect. Med. 2016, 6, a025247. doi:10.1101/cshperspect.a025247

15. Shen, Z.; Ding, B.; Bi, Y.; Wu, S.; Xu, S.; Xu, X.; Guo, Q.; Wang, M. Antimicrob. Agents Chemother. 2017, 61, e01848-16. doi:10.1128/aac.01848-16

16. Coleman, K. Curr. Opin. Microbiol. 2011, 14, 550-555. doi:10.1016/j.mib.2011.07.026

17. González-Bello, C.; Rodríguez, D.; Pernas, M.; Rodríguez, Á.; Colchón, E. J. Med. Chem. 2020, 63, 1859-1881. doi:10.1021/acs.jmedchem.9b01279

18. Papp-Wallace, K. M.; Nguyen, N. Q.; Jacobs, M. R.; Bethel, C. R.; Barnes, M. D.; Kumar, V.; Bajaksouzian, S.; Rudin, S. D.; Rather, P. N.; Bhavsar, S.; Ravikumar, T.; Deshpande, P. K.; Patil, V.; Yeole, R.; Bhagwat, S. S.; Patel, M. V.; van den Akker, F.; Bonomo, R. A. J. Med. Chem. 2018, 61, 4067-4086. doi:10.1021/acs.jmedchem.8b00091
19. Nichols, W. W.; Newell, P.; Critchley, I. A.; Riccobene, T.; Das, S. Antimicrob. Agents Chemother. 2018, 62, e02446-17. doi:10.1128/aac.02446-17

20. van Duin, D.; Bonomo, R. A. Clin. Infect. Dis. 2016, 63, 234-241. doi:10.1093/cid/ciw243

21. Rodriguez, B. A.; Girotto, J. E.; Nicolau, D. P. Curr. Pediatr. Rev. 2018, 14, 97-109. doi:10.2174/1573396314666180308150908

22. Morinaka, A.; Tsutsumi, Y.; Yamada, M.; Suzuki, K.; Watanabe, T.; Abe, T.; Furuuchi, T.; Inamura, S.; Sakamaki, Y.; Mitsuhashi, N.; Ida, T.; Livermore, D. M. J. Antimicrob. Chemother. 2015, 70, 2779-2786. doi:10.1093/jac/dkv166

23. Gordon, E. M.; Duncton, M. A. J.; Gallop, M. A. J. Med. Chem. 2018, 61, 10340-10344. doi:10.1021/acs.jmedchem.8b01389

24. Mushtaq, S.; Vickers, A.; Woodford, N.; Livermore, D. M. J. Antimicrob. Chemother. 2017, 72, 1688-1695. doi:10.1093/jac/dkx035

25. Tehrani, K. H. M. E.; Martin, N. I. Med. Chem. Commun. 2018, 9 , 1439-1456. doi:10.1039/c8md00342d

26. Chalhoub, H.; Sáenz, Y.; Nichols, W. W.; Tulkens, P. M.; Van Bambeke, F. Int. J. Antimicrob. Agents 2018, 52, 697-701. doi:10.1016/j.ijantimicag.2018.07.027

27. Ortiz de la Rosa, J.-M.; Nordmann, P.; Poirel, L. J. Antimicrob. Chemother. 2019, 74, 1934-1939. doi:10.1093/jac/dkz149

28. Ball, M.; Boyd, A.; Ensor, G. J.; Evans, M.; Golden, M.; Linke, S. R.; Milne, D.; Murphy, R.; Telford, A.; Kalyan, Y.; Lawton, G. R.; Racha, S.; Ronsheim, M.; Zhou, S. H. Org. Process Res. Dev. 2016, 20, 1799-1805. doi:10.1021/acs.oprd.6b00268

29. For example BuLi/HMDS, $\mathrm{MeOH} / \mathrm{HCl}$, Trimethylsilylsulfonate were used in different experiments under various conditions.

30. Moss, R. A.; Ma, W.; Merrer, D. C.; Xue, S. Tetrahedron Lett. 1995, 36, 8761-8764. doi:10.1016/0040-4039(95)01925-8

31. The $R$-configuration to the less polar isomer was assigend on the basis of the comparison of the NMR data with the previous literature [32] and with the antibacterial activity of this isomer [32].

32. Abe, T.; Okue, M.; Sakamaki, Y. Optically active diazabicyclooctane derivatives and process for preparing the same. US Pat. Appl. US2012,0165,533A1, June 28, 2012.

33. Dierks, A.; Tönjes, J.; Schmidtmann, M.; Christoffers, J. Chem. - Eur. J. 2019, 25, 14912-14920. doi:10.1002/chem.201903139 


\section{License and Terms}

This is an Open Access article under the terms of the Creative Commons Attribution License (https://creativecommons.org/licenses/by/4.0). Please note that the reuse, redistribution and reproduction in particular requires that the author(s) and source are credited and that individual graphics may be subject to special legal provisions.

The license is subject to the Beilstein Journal of Organic Chemistry terms and conditions:

(https://www.beilstein-journals.org/bjoc/terms)

The definitive version of this article is the electronic one which can be found at:

https://doi.org/10.3762/bjoc.17.60 